УДК 616-001.4:002.3:089:615.246.2:276

(C) 2015

Кулинич С. М., доктор ветеринарних наук

Полтавська державна аграрна академія

\title{
ЛІКУВАННЯ ВИПАДКОВИХ ГНІЙНИХ РАН У КОНЕЙ НА БАЗІ ЧУТІВСЬКОГО КІННОГО ЗАВОДУ «ТРАКЕН»
}

\section{Рецензент - доктор ветеринарних наук А. А. Замазій}

У статті наведені дані щзодо поширення гнійних ран у коней, проведені клінічні, планіметричні дослідження, а також лікування хворих тварин. Встановлено, що аерозольне застосування «Чемі-спрею» 1 раз на добу після виконання первинної хірургічної обробки рани у поєднанні з одноразовим парентеральним введенням $15 \%$ амоксициліну сприяє очищенню

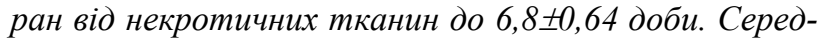
ній термін загоєння становив 23,6£0,64 діб, щзо свідчить про доиільність застосування під час лікування поранених тварин як локальних, так $i$ загальних методів терапіï.

Ключові слова: рани у коней, методи лікування, «Чемі-спрей».

Актуальність проблеми. Значною проблемою під час вирощування, роботи, спортивних змагань та тренінгу коней $є$ травматизм, котрий у структурі захворюваності становить $86 \%$ від загальної кількості хірургічних хвороб, з яких 51,5 \% становлять рани, що ускладнюються розвитком гнійної інфекції [1].

Аналіз останніх досліджень і публікацій, у яких започатковано розв'язання проблеми. Природно, що у коней часті травми. Лошата нерідко отримують їх через свою цікавість і недосвідченість [2, 3].

Мета дослідження - обгрунтувати доцільність застосування аерозолю «Чемі-спрей» у поєднанні 3 парентеральними введеннями $15 \%$ амоксициліну під час лікування поранених коней.

Завдання: на базі Чутівського кінного заводу «Тракен» Полтавської області встановити поширення випадкових гнійних ран у спортивних коней, з'ясувати симптоматику та визначити лікувальну ефективність від локального лікування у поєднанні 3 парентеральними введеннями $15 \%$ амоксициліну.

Матеріали і методи дослідження. Клінікоекспериментальне дослідження проводили протягом 2013 року на базі Чутівського кінзаводу «Тракен». Об’єктом дослідження були коні з випадковими гнійними ранами.

Для вивчення поширення випадкових гнійних ран у коней проводили хірургічну диспансериза- цію поголів'я коней. Тваринам $(\mathrm{n}=5)$ порожнину рани 1 раз на добу промивали розчином $3 \%$ пероксиду водню, після видалення залишків якого, а також авіталізованих тканин, порожнину аерозольно та парентерально одноразово вводили $15 \%$ амоксіцилін із розрахунку 1 мл на 15 кг живої ваги. Процедури проводили до зникнення ознак гнійної ексудації. На 1-y, 3-у, 7-y і 21-у добу лікування проводили планіметричні дослідження. При цьому користувалися методикою Л. Н. Попової [4].

Отриманий експериментальний матеріал опрацьовували методом варіаційної статистики 3 визначенням середніх арифметичних (М) та стандартних відхилень (m).

Результати досліджень. Аналізуючи результати моніторингових досліджень (табл. 1), слід констатувати наступне, що із загальної кількості обстежених протягом року тварин у 16,6 \% були діагностовані рани, водночас у групі кобил хворіло $16,6 \%$, а в групі лошат - 21,4 \%. Досліджуючи сезонність даного захворювання, було встановлено, що кобили хворіли на весні та восени відповідно по 8,3 \%, а лошата восени - 14,2 \% та влітку - 7,1\%. Дані таблиці 2 свідчать, що у кобил травмувалися ділянка шиї та грудної стінки (див. рис.), у лошат травмувалися кінцівки $(14,2 \%)$ та голова $(7,1 \%)$. Вивчаючи причини появи ран у коней було встановлено, що в $100,0 \%$ вони були обумовлені контактом із травмуючими предметами. Зокрема причиною кусано-рваної рани була бійка між кобилами, різано-рваної натикання тварини під час бігу галопом на мангал i, нарешті, причиною різаних ран було травмування об огорожу на спортивному майданчику. У результаті проведених досліджень було встановлено, що найшвидше ознаки гнійної ексудації зникали у п'ятої тварини, а найповільніше - у другої та третьої тварини. Середній термін очищення становив $6,8 \pm 0,64$, діб. $\mathrm{y}$ той же час повне загоювання ран найшвидше реєстрували також у п'ятої тварини, відповідно на 22 добу. Найдовше рана загоювалась, відповідно, у другої тварини - 25 діб. Середній термін загоєння становив $23,6 \pm 0,64$ діб. 
BETЕРИНАРНА МЕДИЦИНА

\section{1. Розповсюдження випадкових гнійних ран у коней на базі Чутівського кінзаводу "Тракен»}

\begin{tabular}{|c|c|c|c|c|c|c|c|c|c|c|c|}
\hline \multirow{3}{*}{$\begin{array}{c}\text { Статевовікові } \\
\text { групи }\end{array}$} & \multirow{3}{*}{$\begin{array}{c}\text { Обстежено } \\
\text { голів }\end{array}$} & \multicolumn{10}{|c|}{ Виявлено травмованих тварин } \\
\hline & & \multicolumn{2}{|c|}{$\begin{array}{c}\text { протягом } \\
\text { року }\end{array}$} & \multicolumn{2}{|c|}{ осінь } & \multicolumn{2}{|c|}{ зима } & \multicolumn{2}{|c|}{ весна } & \multicolumn{2}{|c|}{ літо } \\
\hline & & гол. & $\%$ & гол. & $\%$ & гол. & $\%$ & гол. & $\%$ & гол. & $\%$ \\
\hline Жеребці & 4 & 0 & 0 & 0 & 0 & 0 & 0 & 0 & 0 & 0 & 0 \\
\hline Кобили & 12 & 2 & 16,6 & 1 & 8,3 & 0 & 0 & 1 & 8,3 & 0 & 0 \\
\hline Лошата & 14 & 3 & 21,4 & 2 & 14,2 & 0 & 0 & 0 & 0 & 1 & 7,1 \\
\hline Усього & 30 & 5 & 16,6 & 3 & 10 & 0 & 0 & 1 & 3,3 & 1 & 3,3 \\
\hline
\end{tabular}

\section{2. Локалізація ран у коней}

\begin{tabular}{|c|c|c|c|c|c|c|c|c|c|c|c|}
\hline \multirow{3}{*}{$\begin{array}{c}\text { Статевовікові } \\
\text { групи }\end{array}$} & \multirow{3}{*}{$\begin{array}{l}\text { Кількість } \\
\text { тварин }\end{array}$} & \multicolumn{10}{|c|}{ Місця локалізації ран } \\
\hline & & \multicolumn{2}{|c|}{ кінцівки } & \multicolumn{2}{|c|}{$\begin{array}{c}\text { шия, } \\
\text { холка, } \\
\text { спина }\end{array}$} & \multicolumn{2}{|c|}{$\begin{array}{c}\text { грудна, черев- } \\
\text { на стінка }\end{array}$} & \multicolumn{2}{|c|}{$\begin{array}{c}\text { сечостатеві } \\
\text { органи }\end{array}$} & \multicolumn{2}{|c|}{ голова } \\
\hline & & гол. & $\%$ & гол. & $\%$ & гол. & $\%$ & гол. & $\%$ & гол. & $\%$ \\
\hline Жеребці & 4 & 0 & 0 & 0 & 0 & 0 & 0 & 0 & 0 & 0 & 0 \\
\hline Кобили & 12 & 0 & 0 & 1 & 8,3 & 1 & 8,3 & 0 & 0 & 0 & 0 \\
\hline Лошата & 14 & 2 & 14,2 & 0 & 0 & 0 & 0 & 0 & 0 & 1 & 7,14 \\
\hline Усього & 30 & 2 & 6,6 & 1 & 3,3 & 1 & 3,3 & 0 & 0 & 1 & 3,3 \\
\hline
\end{tabular}

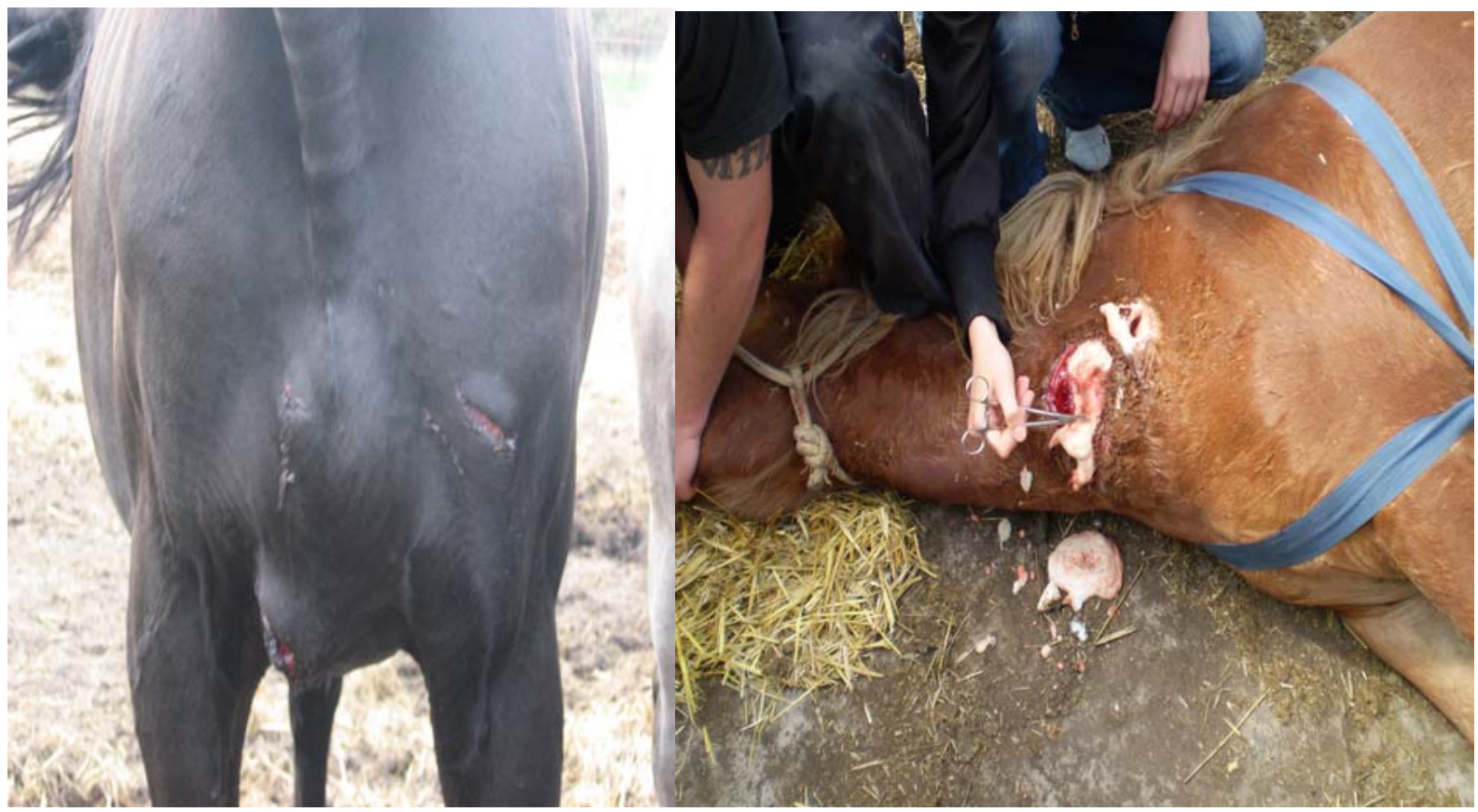

\section{Рис. Випадкові гнійні рани в коней}

Площа ранової поверхні у тварин у процесі лікування істотно зменшилася (табл. 3).

Через добу розміри ран незначно збільшувалися, хоча вже на третю добу лікування вони зменшувалися на $3 \%$.
Відповідно на сьому добу відносно вихідних даних показники знизилися на $27,5 \%$ та на $26,3 \%$ - через 3 доби.

Кінцеві показники були у 2,7 рази меншими за порівняння з вихідними даними. 


\section{ВЕТЕРИНАРНА МЕДИЦИНА}

\section{3. Динаміка площі ранової поверхні під час лікування коней}

з інфікованими ранами, $\mathrm{cm}^{2}, M \pm m$

\begin{tabular}{|c|c|c|}
\hline \multicolumn{2}{|c|}{ Показники } & Розмір дефекту \\
\hline \multirow{3}{*}{$\begin{array}{c}\text { Доба } \\
\text { лікування }\end{array}$} & 1 & $10,2 \pm 0,36$ \\
\cline { 2 - 3 } & 3 & $9,9 \pm 0,64$ \\
\cline { 2 - 3 } & 7 & $7,4 \pm 0,36$ \\
\cline { 2 - 3 } & 21 & $3,7 \pm 0,18$ \\
\hline
\end{tabular}

Висновок. 3'ясовано, що запропонований метод лікування гнійних ран у коней $є$ досить ефективним підтвердженням чого є кінцеві показни-

\section{БІБЛІОГРАФІЯ}

1. Мельник Н. Лечение надрывов сухожилий на ногах у лошадей / Н. Мельник [Електронний pecypc]. - Режим доступу : http://www.proza.ru $/ 2010 / 10 / 22 / 1420$

2. Романова О. В., Крячко О. В., Синицина Е.А. Деликатное лечение гнойных ран у лошадей / О.В. Романова, О.В.Крячко, Е. А. Синицина ки розмірів ранових дефектів, які на 21-у добу були у 2,7 рази меншими за порівняння 3 вихідними даними.

[Електронний ресурс]. - Режим доступу : http://zooprice.ru/articles/detail.php?ID $=454245$

3. Тимофеев C. B. Раны и их лечение у животных / С. В. Тимофеев. - М., 2007.

4. Раны и раневая инфекция : [под ред. В. О. Кузина, Б. М. Костюченок / 2-е изд., перераб. и доп.]. - М. : Медицина, $1990-592$ с. 